Doing so has value well beyond the particular training needed by historians or teachers. Taking a community seriously beyond stereotype and generalization, reckoning with what a community has said about itself and its schools, pushes future teachers and historians to conceive of their work in terms broader than filling in historiographical gaps or crafting lesson plans. These experiences serve as reminders to listen. They push students not to complacently accept the categorizations and labels so easily, and often falsely, applied to urban and black communities, but instead to listen to those communities and their representations of their own stories. These reminders helped future teachers in the course identify the need to get to know the communities in which they would be teaching. And these reminders to listen, attached not to abstract historical actors but to particular voices encountered in interviews and in the archive, brought the ethically weighty work of historical representation to the forefront of future historians' thinking. With these conversations in mind, I look forward to further collaboration on the history of education in Harlem.

\title{
Future Teachers and Historical Habits of Mind: A Pedagogical Case Study
}

\section{Heatber Lewis}

\section{Course: Roots of Urban Education (graduate course in teacher education)}

Institution: Pratt Institute, Brooklyn, New York

For the past ten years, I have taught the Roots of Urban Education, a graduate-level course for preservice art teachers and librarians, and have used the course as a pedagogical case study to help improve my teaching. Given that this is the only history course students in the teacher education program are required to take, the course emphasizes depth over breadth through a place-based study of schooling during key reform eras in twentieth-century New York City. I documented, analyzed, and revised my teaching, with special focus on my expectation

Heather Lewis is professor and acting chair of Art and Design Education at Pratt Institute. Lewis's historical research explores the intersection of urban social movements and institutional reform. She also conducts research on teaching, learning and assessment. She thanks her current and former students for their critical and creative feedback. 
that students would develop historical habits of mind and that such competencies would be relevant for future teachers.

Initially, this examination of my teaching grew out of desperation rather than insight. I had few opportunities for collegial discussion and feedback-I am the only historian in my program-and scarce support on campus for teaching and learning. Fortunately, the scholarship of teaching and learning "movement" took off just as I started teaching and I reached out to historians engaged in this new pedagogical turn in the field. ${ }^{1}$ The first part of this essay considers the movement's pedagogical relevance for faculty who do not teach in traditional history programs. The second part describes course context, content, and pedagogical strategies as my teaching evolved.

\section{Disciplinary and Cross-Disciplinary Signature Pedagogies}

At the 2007 conference of the History of Education Society, Lendol Calder, chair of the Department of History at Augustana College and a Carnegie Scholar in the scholarship of teaching and learning, posed and discussed the following question, "How can we know that we have effectively uncovered the signature moves of historical thinking?"2 Calder argued that the moment was ripe for identifying the signature pedagogies in history survey courses, given cognitive scientists' contributions to principles of learning and historians' efforts to redesign the survey. He suggested that, beginning with the history survey, students should experience "ways of being taught that require them to do, think, and value what practitioners in the field are doing, thinking, and valuing." 3 However, Calder argues that most historians are consumed with what

'Lee S. Shulman, "Signature Pedagogies in the Professions," Dadalus 134, no. 3 (Summer 2005): 52-59; Lee S. Shulman, "Pedagogies of Uncertainty," Liberal Learning 91, no. 2 (Spring 2005): 18-25. For general sources about the scholarship of teaching and learning, see Ernest L. Boyer, Scholarsbip Reconsidered: Priorities of the Professoriate (Princeton, NJ: Carnegie Foundation for the Advancement of Teaching, 1990); Pat Hutchings, ed., The Course Portfolio: How Faculty Can Examine Their Teaching to Advance Practice and Improve Student Learning (Washington, DC: American Association for Higher Education, 1998); Pat Hutchings, ed., Opening Lines: Approacbes to the Scholarship of Teacbing and Learning (Menlo Park, CA: Carnegie Foundation for the Advancement of Teaching, 2000); Mary Taylor Haber and Pat Hutchings, The Advancement of Learning: Building the Teaching Commons (San Francisco, CA: Jossey-Bass, 2005); Pat Hutchings, Mary Taylor Huber, and Anthony Ciccone, The Scbolarsbip of Teaching and Learning Reconsidered: Institutional Integration and Impact (San Francisco, CA: Jossey-Bass, 2011); and Kathleen McKinney and Nancy L. Chick, The Scbolarship of Teaching and Learning In and Across the Disciplines (Bloomington: Indiana University Press, 2013).

${ }^{2}$ Lendol Calder raised this question earlier in his seminal 2006 article, "Uncoverage: Towards a Signature Pedagogy for the History Survey," Fournal of American History 92, no. 4 (March 2006): 1358-70. William Cutler, an education historian and a Carnegie Scholar with Calder, generously reviewed my teaching portfolio as it evolved over time.

${ }^{3}$ Calder, "Uncoverage," 1361. 
to teach rather than bow to teach. Calder applies Grant Wiggins and Jay McTighe's notion of uncoverage as a way of exposing what it "really means to be good at history."

While Calder focused on redesigning the survey itself, others overhauled their history programs, beginning with the survey. John Savagian, professor of history at Alverno College, and the history faculty at Alverno College redesigned their program by integrating content with the learning process. Savagian argues that "while content might be absorbed at any point in a student's college life, abilities are developmental." With this in mind, the program now offers metacognitive skills in the freshman year so that students begin to develop historical habits of mind. Students are prepared to read and interpret primary sources and ask historical questions. They then systematically integrate content with ability across their history courses as they move through three developmental levels.

In contrast to Savagian and his colleagues at Alverno, who were able to integrate the teaching of historical content with historical methodology across several courses, I had to do this in one course. Because my students are not history majors and will not take another history course in their graduate program, I had qualms about asking them to develop competencies in another discipline. My initial instinct was that the signature pedagogies in history could undergird and reinforce habits of mind in other disciplines, specifically art and design.

When I first designed the course, I asked, "What do I want graduate students who are pursuing a degree in teaching to learn about the history of education in my course?" This question changed to "What do I want them to be able to do?" Gradually I adopted the following outcomes from the American Historical Association (AHA) Tuning Project: ${ }^{5}$

- Take argumentative risks and acknowledge contradictory perspectives.

- Practice historical empathy.

- Interpret the past in context.

- Generate open-ended questions about the past.

- Explore the dynamics of historical change over time.

- Craft historical argument and narrative and defend it publicly.

I then explored signature pedagogies in the teaching of art and design and their relationship to the historical habits of mind I wanted

${ }^{4}$ John C. Savagian, "Toward a Coherent Curriculum: Teaching and Learning History at Alverno College," Fournal of American History 95, no. 4 (March 2009): 1117, $1114-24$

5"2013 Tuning Core Document," American Historical Association, http://www. historians.org/teaching-and-learning/current-projects/tuning/history-discipline-core. 
my students to develop. I looked for overlaps and commonalities that would link students' disciplines with the underlying habits of mind I hoped to engender. I found, for example, that in art and design, knowledge is procedural and entails "knowing through embodied, sensory, and emotional ways" as students enter uncertain territory that leads to unique outcomes. ${ }^{6}$ Students are challenged to form their own judgments and experiment with materials and processes. ${ }^{7}$ While such competencies might appear to be unrelated to the historical competencies listed above, I would argue that, just as artists and designers are expected to be able to be comfortable with uncertainty and ambiguity, historians are expected to do the same as they explore multiple viewpoints and perspectives and enter uncertain territories. Similar to art and design students, history students are also to form their own judgments as they craft historical arguments, defend them publicly, and revise them when new evidence requires it. Like historians, students in the art and design studio participate in critiques in which they discuss and defend their work publicly. ${ }^{8}$ Given these related disciplinary habits of mind, I sought to help students make metacognitive connections between the competencies they were expected to develop in my course and their studio-based competencies.

In spite of increasing evidence that demonstrated my students were capable of the challenges I set them, I had a nagging sense that I was asking them to develop competencies that take historians many years to develop. Was I asking them to mimic the processes, rather than to develop the competencies? As Keith Erekson asks, "Can students really practice history the same way that trained historians do?" 9 These concerns led me to systematically assess the quality of student work and their responses to a set of survey questions I administered at the end of each year's course. My students' survey responses suggested that, on the whole, students were prepared to take on my course expectations and, after an initial period of anxiety and puzzlement, changed their views about the value of learning how to "do" history. An international student described this transition:

\footnotetext{
${ }^{6}$ Ellen Simms and Alison Shreve, "Signature Pedagogies in Art and Design," in Exploring More Signature Pedagogies: Approaches to Teacbing Disciplinary Habits of Mind, eds. Nancy L. Chick, Aeron Haynie, and Regan A. R. Gurung (Sterling, VA: Stylus Publishing, 2012), 59, 55-67.

${ }^{7}$ Ibid., 59.

${ }^{8}$ Ibid., 61; Helen Klebesadel and Lisa Kornetsky, "Critique as Signature Pedagogy in the Arts," in Exploring Signature Pedagogies: Approaches to Teaching Disciplinary Habits of Mind, eds. Nancy L. Chick, Regan A. R. Gurung, and Aeron Haynie (Sterling, VA: Stylus Publishing, 2009), 99-121; and Tom Schrand and John Eliason, "Feedback Practices and Signature Pedagogies: What Can the Liberal Arts Learn from the Design Critique?," Teaching in Higber Education 17, no. 1 (February 2012): 51-62.

${ }^{9}$ Keith A. Erekson, "Putting History Teaching 'In its Place," Fournal of American History 97, no. 4 (March 2011): 1070, 1067-78.
} 
I'm not a history major and I thought, oh now, this is too much . . . the course was very text-based and I panicked. But when we went on the walking tour of the Lower East Side and looked at the old school buildings it made it all real for me. I realize now that without this course I would not understand the NYC school system, I would have no context. I also realized that the course trained me to think and how to write, this was the best writing I have done in the program. Going back and forth between the visual and textual also helped me think and sift through the relevant part of history. I had to search to find invisible sources that seemed to be hidden from the public.

My analysis of students' work generally reinforced their survey responses. For example, the above student, a printmaker, discovered a digital version of a booklet produced for the New York City based America's Making Exposition of 1921. This led her on a quest for additional primary sources and a review of secondary sources. For her culminating public exhibit, she designed wallpaper from the booklet cover and a book that symbolized W. E. B. Du Bois and Carter G. Woodson's role in using "civic celebration to induce educational reform." ${ }^{10}$ Her exhibit demonstrated that it was possible for students to simultaneously develop their methodological skills and explore complex historical content. To make this possible, the course content emphasizes depth over breadth. This student had the time to explore and interpret sources she claims were hidden from the public because so few historians had written about Du Bois and Woodson's role in a major public exposition seemingly devoted to immigration. In the process, the student developed a more nuanced understanding of the historical continuities in the teaching of African-American history.

\section{Course Context, Content, and Pedagogical Strategies}

The course context is both similar and distinct from many teacher education programs. On the whole, my students fit the typical preservice profile-mostly white, female, and middle class. Yet there are also a number of international students and students of color. Because this is a preservice program for future art and design teachers, as well as school librarians, their disciplinary backgrounds shape their approach to learning. But so do their ethnic, racial, gender, socioeconomic, and national backgrounds. As a white female professor whose research explores the juncture of the Northern civil rights movement and education in New York City, I explicitly address my racial and class background with students at the beginning of the course and describe how it influenced my intellectual journey. I explain that while one of the course outcomes is to help them view historical events from multiple perspectives, they

${ }^{10}$ For sample work, see Heather Lewis's website, http://www.heatherblewis.com. 
need to remain conscious of how their own background influences their interpretations and inquiry.

This type of self-awareness develops gradually. One graduate student wrote in a survey response, "This class has reemphasized the importance of looking at history through lenses other than your own, be it from a different ethnicity, gender, or time." To be sure, students do not necessarily start the course with this insight. They wrestle with uncomfortable responses to Jacob Riis's stereotypical images and writing about white, Asian, and black residents of New York City's Lower East Side. White students, in particular, distance themselves from the history of "whiteness" at the beginning of the twentieth century, arguing that it is not the same today. ${ }^{11}$ Yet this defensive response generally recedes as students develop the capacity to contextualize historical events, analyze historical continuity, and identify the difference between structure and agency.

Students explore the relationship between structural forces, such as ethnic and racial segregation and Americanization, and the agency of those who lived and wrestled with such forces during the Progressive Era on the Lower East Side, the Harlem Renaissance, and the long civil rights movement in Ocean Hill-Brownsville. For example, students read primary sources by teachers and principals working on the Lower East Side and in East Harlem who either supported or redefined the dominant, assimilationist thrust of public schooling. They read public debates among Harlem Renaissance intellectuals about the role of the arts in addressing racism and social change. And they consider community activists' diverse responses to school segregation in Ocean Hill-Brownsville.

I introduce students to the concept of place-based history through historical exhibits and tours, such as the one hundredth anniversary of the Great Migration era; a walking tour of Progressive Era public school buildings, libraries, and tenements on the Lower East Side; and a visit to the Schomburg Center for Research in Black Culture in Harlem. The goal is to not only experience a sense of place but to become more familiar with sites where historians "do history" and share their work with the public. ${ }^{12}$ Through these visits, students get a better sense of what they will be expected to do by the end of the course-conduct independent historical research, write a historical essay, and design a public history exhibit.

After immersing themselves in the physical space of particular communities and their institutions, students participate in Socratic seminar

\footnotetext{
"Nell Irvin Painter, The History of White People (New York: W. W. Norton, 2010).

${ }^{12}$ Erekson, "Putting History Teaching 'In Its Place."
} 
discussions of assigned primary sources by individual reformers and activists, many of them educators or community leaders, and secondary sources, including films and videos that provide structural overviews. Students complete scaffolded assignments that provide multiple opportunities to practice formulating historical questions and arguments.

Throughout this process, students use concept mapping, which helps them trace the relationship between concepts and develop metacognitive skills. ${ }^{13}$ Concept maps also help students become more aware of their historical thinking as they become more adept at interpretation, analysis, and making connections. I meet with students individually throughout the course to help them revise their mind maps as their thinking evolves. Students describe their growth as learners through this iterative process; in one survey response, a student noted, "I found it hard at first to identify different claims and biases, but the more I made historical questions and arguments, the more confident I felt about it." Another student noted, "I learn from reading and constructing my question and argument and then learn (a third time) during seminars; they sometimes inspire me to rethink my point of view!"

The final essay and exhibit challenges students to further develop their skills by requiring them to independently identify and interpret multiple primary sources, synthesize and contextualize their arguments, and make them public. Students then write an essay geared to a public history exhibit installed in a gallery space. At the gallery opening, students work in teams on thematically linked exhibits and participate in public conversations about their historical topics. I use two different rubrics to assess the essay and exhibit, providing students with a clear definition of the expected competencies. A student described the final exhibit and how working with a partner and focusing on visual images helped her synthesize her argument:

I always wanted to do a project like this! It helped working together with another student. I felt so much more positive being able to articulate ideas visually. Also, I felt my learning was stronger and I was more enthusiastic about the topic. Collaboratively, my partner and I worked really well together. The exchange between topics was also very nice and I feel we made a good visual synthesis of ideas and images.

My hope is that students will discover that their newly developed historical habits of mind are relevant in new settings, especially when they start teaching. One student noted:

${ }^{13}$ Ibrahim M. R. Al-Shaer, "Employing Concept Mapping as a Pre-Writing Strategy to Help EFL Learners Better Generate Argumentative Compositions," International Fournal for the Scholarship of Teaching and Learning 8, no. 2 (July 2014): 1-29. 
I was actually worried that I wouldn't like the class because I have not particularly enjoyed past history classes. The course has changed my feelings dramatically. If I do not end up working in New York, I will research the history of education in the state I end up working in. The course has shown me the relevance of the history of education, within each state, to present-day education.

Despite this student's claim, I do not really know if she will transfer her historical competencies to her future career. Students complete exit surveys about their course experiences when they leave our program and some complete surveys a year after graduation, but the questions are too general for me to ascertain whether the transfer of historical competencies to teaching practice actually happens. Nor do I really know if students are able to apply their ability to consider multiple points of view when they are teaching students from diverse racial, ethnic, socioeconomic, and gendered backgrounds. However, this pedagogical case study suggests that these are the kinds of questions that should inform my future scholarship of teaching and learning.

\title{
Civil Rights, Educational Inequality, and Transnational Takes on the U.S. History Survey
}

\author{
Laura K. Muñoz
}

\section{Course: U.S. History Since 1865 (survey course) \\ Institution: Texas A\&M University-Corpus Cbristi}

In Mexicans in the Making of America, historian Neil Foley reconceptualizes Manifest Destiny, not as the glorious westward push of European Americans, but as their arrival on the doorstep of Mexican America. ${ }^{1} \mathrm{He}$ argues that the United States came to Mexico, and we must reimagine

\footnotetext{
Laura K. Muñoz is an associate professor of history at Texas A\&M University-Corpus Christi and a former National Academy of Education/Spencer Postdoctoral Fellow. She specializes in the history of race, gender, and education in the Southwest. Thank you to Natasha M. Crawford, Veronica Guzman Hays, and an endowment from the Paul and Mary Haas Foundation.
}

'Neil Foley, Mexicans in the Making of America (Cambridge, MA: Belknap Press of the Harvard University Press, 2014). 